\title{
Editorial: an introduction and welcome to Hypoxia
}

This article was published in the following Dove Press journal:

Hypoxia

31 October 2013

Number of times this article has been viewed

\section{Dörthe M Katschinski}

Institute of Cardiovascular Physiology, University Medical Center Göttingen, Georg-August University Göttingen, Göttingen, Germany
Correspondence: Dörthe M Katschinski Institute of Cardiovascular Physiology, University Medical Center Göttingen, Georg-August University Göttingen, Humboldtallee 23, 37073 Göttingen,

Germany

Fax: +49 55। 395895

Email doerthe.katschinski@med.

uni-goettingen.de
Hypoxia can influence many aspects of physiology and pathophysiology, including high altitude, embryonic development, wound healing, anemia, inflammation, cancer, and ischemic diseases, such as infarction and stroke.

Researchers involved in hypoxia-related science are from a variety of different fields, and include cell biologists, molecular biologists, and clinical scientists. The research being done in this field will help us to gain a better understanding of the physiologic processes involved and to develop new therapies for the above-mentioned diseases. A detailed knowledge of the mechanisms of hypoxia sensing, signaling, and adaptation is important to achieve these goals and ultimately exploit this signaling pathway for therapeutic applications. Together with scientists from HypoxiaNet, a COST Action (Cooperation in Science and Technology) funded by the European Union, Dove Press has developed and established Hypoxia, a new open-access peerreviewed journal. The advent of a journal dedicated to hypoxia-related research is considered to be one way to bundle the already existing but widespread research activities in this field. Early in the development process, many leading scientists have agreed to support the journal as editorial board members. In addition, widely recognized experts are preparing review articles that are scheduled to appear in early 2014 to set the standard and thematic ground for the journal. As the Editor-in-Chief, I am grateful for this wonderful support.

Every scientist knows that, in times of financial pressure, to get scientific projects funded and while the run after high-impact factor publications is on, it is not an easy task to develop a new journal from scratch. I sincerely hope that the journal will be accepted within the hypoxia research community as a platform serving basic and applied research on hypoxia signaling pathways, thereby accelerating scientific progress at the levels of basic science, technology, pharmacology, and translational medicine. Together with the editorial team at the journal's office, we will ensure a rapid and transparent review process. The journal welcomes papers from all regions of the world that address any aspect of hypoxia sensing, signaling, and adaptation. This "open-access" journal will ensure that cutting edge knowledge will be freely available to researchers worldwide.

\section{Disclosure}

The author reports no conflicts of interest in this work. 
Hypoxia

Dovepress

\section{Publish your work in this journal}

Hypoxia is an international, peer-reviewed, open access journal that aims to improve understanding of the biological response to hypoxia. The journal will publish original research articles, reviews, methodological advances, clinical studies, and expert opinions that identify developments in the regulation of the physiological and pathological responses to The manuscript management system is completely online and includes a very quick and fair peer-review system, which is all easy to use. Visit http://www.dovepress.com/testimonials.php to read real quotes from published authors. 